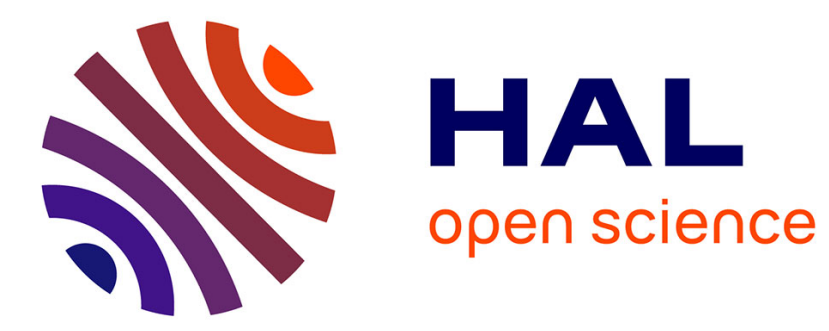

\title{
Diel nectar secretion rhythm in squash (Cucurbita pepo) and its relation with pollinator activity
}

Andrea Edge, Byron Nest, Jennifer Johnson, Samara Miller, Nick Naeger, Sam Boyd, Darrell Moore

\section{- To cite this version:}

Andrea Edge, Byron Nest, Jennifer Johnson, Samara Miller, Nick Naeger, et al.. Diel nectar secretion rhythm in squash (Cucurbita pepo) and its relation with pollinator activity. Apidologie, 2011, 43 (1), pp.1-16. 10.1007/s13592-011-0087-8 . hal-01003625

\section{HAL Id: hal-01003625 \\ https://hal.science/hal-01003625}

Submitted on 1 Jan 2011

HAL is a multi-disciplinary open access archive for the deposit and dissemination of scientific research documents, whether they are published or not. The documents may come from teaching and research institutions in France or abroad, or from public or private research centers.
L'archive ouverte pluridisciplinaire HAL, est destinée au dépôt et à la diffusion de documents scientifiques de niveau recherche, publiés ou non, émanant des établissements d'enseignement et de recherche français ou étrangers, des laboratoires publics ou privés. 


\title{
Diel nectar secretion rhythm in squash (Cucurbita pepo) and its relation with pollinator activity
}

\author{
Andrea A. Edge ${ }^{1}$, Byron N. van Nest ${ }^{1}$, Jennifer N. Johnson ${ }^{1}$, Samara N. Miller ${ }^{1}$, \\ Nick NAEGER ${ }^{2}$, Sam D. BOYD ${ }^{1}$, Darrell MOORE ${ }^{1}$ \\ ${ }^{1}$ Department of Biological Sciences, East Tennessee State University, Box 70703, Johnson City, TN 37614, USA \\ ${ }^{2}$ Department of Entomology, University of Illinois at Urbana-Champaign, Urbana, IL, USA
}

Received 17 August 2010 - Revised 20 April 2011 - Accepted 3 June 2011

\begin{abstract}
Most studies of foraging behavior in bees have been performed under artificial conditions. One highly neglected area is the daily nectar secretion rhythm in flowers including how nectar properties may vary with time of day. As a first step in understanding the connections between forager behavior and nectar presentation under more natural conditions, we examined nectar secretion patterns in flowers of the squash Cucurbita pepo. Under greenhouse conditions, squash flowers exhibit consistent diel changes in nectar volume and concentration through anthesis. These temporal patterns are robust, persisting under field conditions as well as simulated drought conditions in the greenhouse. In the presence of active pollinators, diel patterns are evident but with highly variable, severely reduced volumes. The potential consequences of these factors for pollinator behavior are discussed.
\end{abstract}

bees / foraging / nectar / pollinators / behavior

\section{INTRODUCTION}

In angiosperm-pollinator communities, bees typically are the dominant pollinators (Proctor et al. 1996). The ability to recruit hive mates efficiently gives honey bees (von Frisch 1967; Visscher and Seeley 1982; Seeley 1995) and stingless bees (Nieh et al. 2003) the capacity to quickly exploit productive nectar sources and accumulate nectar for future use. Solitary bees, including carpenter bees (Louw and Nicolson 1983), collect pollen and nectar simultaneously. One aspect of flower-pollinator systems that has received relatively little attention is the dynamic between bee activity and changes in nectar properties (i.e., volume and sugar concentration) throughout the day.

Corresponding author: D. Moore, moored@etsu.edu Manuscript editor: Bernd Grünewald
Virtually all of our current information on the relationship between nectar quality and quantity and bee behavior is based on experiments in which the bees are presented sucrose solution from artificial feeders during a restricted time period for one or more consecutive days. How closely do these artificial situations approximate the reward structure provided by natural flower patches? What is the day-to-day precision in the onset of nectar availability for individual flowers of the same species within a patch? Is there significant variation from flower to flower? Does nectar secretion within individual flowers vary predictably with time of day? How will floral nectar rhythms be influenced by weather conditions and, consequently, soil water content? To address these fundamental questions, we first must understand how nectar volume and concentration vary in individual flowers across the entire duration of anthesis. 
Forager honey bees apparently assess the profitability of nectar rewards by evaluating a number of factors including sugar concentration, nectar volume, flight distance from the hive, weather conditions, wind speed and direction, level of difficulty in obtaining nectar from the flowers, abundance of nectar within the patch, and nutritional status of the colony (Vansell 1934; Kleber 1935; von Frisch 1942; Butler 1945; Lindauer 1948; Schua 1952; Boch 1956; Waddington 1982, 1985; Seeley 1986, 1989; Seeley et al. 1991). Studies using artificial feeders that regulate sucrose solution flow rates (Nuñez 1966) have shown that, although honey bee foragers increase their final crop loads at the food source in response to increases in both sucrose concentration and solution flow rate, the salient cue for modification of crop loading apparently is sucrose flow (i.e., number of sucrose molecules per unit time), independent of concentration and solution flow rate (Varju and Nuñez 1991). Similarly, given a choice among several simultaneous feeders delivering sucrose solutions at different solution flow rates and concentrations, the relative choice frequencies of honey bee foragers were similar if the sucrose flow rates were the same (Greggers et al. 1993).

Unfortunately, detailed information on floral nectar secretion with respect to time of day has rarely captured the attention of researchers (Nepi et al. 2001). In one of the relatively few such studies, Núñez (1977) found that, despite a nearly constant rate of nectar secretion throughout the day in five species of flowers, the "sugar gathering flow" by honey bees showed enormous changes, perhaps related to a shift in foraging behavior. Determinations of nectar volume and concentration often are difficult for many species because nectaries are small and inconvenient for nectar extraction via micropipette. Also, in the field, it is necessary to shield the flowers from natural pollinators and the shielding methods themselves may influence the nectar volume and concentration measurements (Corbet and Wilmer 1981; Corbet and Delfosse 1984; Wyatt et al. 1992). Furthermore, there may be flower-to-flower differences in microclimate within a flower patch: increases in humidity, for example, often yield higher nectar volumes and lower sugar concentrations (Corbet 1978; Corbet et al. 1979).

In a first step towards understanding the relationship between diel changes in nectar characteristics (i.e., volume and concentration) and pollinator activity, we chose to examine the nectar of yellow crookneck squash (Cucurbita реро L., variety 'Summer Crookneck') throughout anthesis. This squash has agricultural importance and many commercial plantings currently are pollinated by European honey bees in addition to native pollinators such as bumble bees (Bombus spp.) and squash bees (Peponapis and Xenoglossa spp.) (Nepi et al. 2001). Squash, as well as other cucurbits, exhibit a pronounced daily rhythm of anthesis: the flowers open before sunrise and close by midday. Our primary goals were to describe, in detail, (1) how volume and sugar concentration in squash nectar change within the daily timewindow of anthesis, (2) how the nectar secretion pattern is influenced by changes in soil water content, (3) how the nectar secretion pattern compares between controlled greenhouse conditions and that seen in the field, and (4) how honey bees as well as native pollinators schedule their foraging flights relative to the daily nectar secretion pattern.

\section{MATERIALS AND METHODS}

\subsection{Greenhouse study: nectar secretion patterns}

The existence or absence of any daily variations in nectar secretion during anthesis was determined with respect to both sugar concentration and fluid volume. Performance of this study within the greenhouse enabled the exclusion of all possible nectar foragers as well as control of watering conditions. The first greenhouse study, comprising two trials (64 and 100 plants, respectively), was conducted during 6-8 July, 2007 and 19-21 May, 2008 in a metal-frame greenhouse on the main campus of East Tennessee State 
University, Johnson City, Tennessee. Squash plants $(C$. pepo variety 'Summer Crookneck') were grown from seed (Burpee Seed Company) in separate 3-gal plastic pots using a 1:5:5 mixture of sand, composted manure (Black Kow), and Fafard 3B soil. Male blossoms were present in abundance and were used exclusively, thereby avoiding male-female differences in nectar volume and concentration (Nepi et al. 2001; CantoAguilar and Parra-Tabla 2000). All of the plants were watered each evening (between 1700 and $2100 \mathrm{~h}$ ). Beginning 3 days prior to the onset of sampling, each plant received $500 \mathrm{ml}$ of water. Sampling occurred over three consecutive days: nectar extractions were taken from 5-10 randomly selected, open male squash blossoms every $90 \mathrm{~min}$ each day from 0500 to $1230 \mathrm{~h}$ (trial 1) and from 0430 to $1200 \mathrm{~h}$ (trial 2) using $10 \mu \mathrm{l}$ or $20 \mu \mathrm{l}$ microcapillary tubes (Drummond Wiretrol). To prevent pseudoreplication, blossoms from the same plant were never taken more than once per sample time nor in consecutive sample times. On some days, there were fewer samples $(N=3-4)$ at the first sampling time because most of the flowers had not yet opened. Similarly, occasionally, there were fewer samples $(N=2-4)$ at the last sampling time because most of the flowers had already closed. For each sample, the nectar was completely drained and the flower was discarded. Although the influence of flower removal on nectar flow in the remaining blossoms of the same plant was not tested specifically, we found no evidence of altered nectar flow in the relatively few flowers taken each day from previously sampled plants. Volume was determined from the fluid level in the calibrated micropipettes. Sugar concentration $(\mathrm{w} / \mathrm{w})$ was measured with a handheld Bellingham and Stanley, Model 45-81 refractometer (Corbet et al. 1979) immediately following the volume measurement in order to minimize evaporation. Very small volumes $(<1 \mu \mathrm{l})$ in some early morning extractions precluded some nectar concentration measurements. The rate of nectar sugar production was estimated for $1.5 \mathrm{~h}$ increments through anthesis by first determining the difference in mean volumes measured from two successive sample times, then (using the average nectar concentration between the two sample times) calculating the total amount of sugar (mg) by standard methods (Bolten et al. 1979; Kearns and Inouye 1993), and finally dividing the total sugar by 1.5 to yield the estimated rate $(\mathrm{mg} / \mathrm{h})$.

\subsection{Greenhouse study: simulated drought}

Blooming squash plants in the greenhouse were subjected to drought conditions in order to assess the impact of water deprivation on nectar secretion patterns. Two trials were conducted, using 161 and 183 plants, respectively. Nectar volume and concentration measures were taken on each day of both trials, using the same methods described in "Green house study: nectar secretion patterns". The first trial (13-28 September, 2007) was conducted over 16 consecutive days, encompassing the following sequence: 3 days of baseline watering $(500 \mathrm{ml}$ per day per plant, as described above), 1 day of $250 \mathrm{ml}$ per plant, nine consecutive days during which water was discontinued (the simulated drought), 1 day of $1,000 \mathrm{ml}$ per plant (a simulated rain event), and three consecutive days of a return to baseline watering (500 ml/plant). Samples were taken every $90 \mathrm{~min}$, beginning at $0430 \mathrm{~h}$ and ending with a $1200 \mathrm{~h}$ sampling time. Sample sizes ranged from five to 15 blossoms at each sample time each day except for the $1200 \mathrm{~h}$ sample time on days 14 and 16, during which no flowers were available. In the second trial (25 consecutive days-17 July through 10 August, 2008), each plant received $500 \mathrm{ml}$ of water for the first 4 days of the experiment, after which an artificial drought was imposed, in which the plants received no water for 16 consecutive days. On the first day following the simulated drought (day 21), each plant received $1,000 \mathrm{ml}$ of water (simulating a rain event), after which the original $500 \mathrm{ml} /$ day was resumed for the final 4 days of the experiment. Nectar samples were taken every $90 \mathrm{~min}$ from 0500 to $1230 \mathrm{~h}$ each day. Sample sizes ranged from eight to 12 during the 0630, 0800, 0930, and $1100 \mathrm{~h}$ sample times, from six to 10 during the $0500 \mathrm{~h}$ sample time (except for 0 on day 3), and from 0 to 14 at the $1230 \mathrm{~h}$ sample time (no flowers were available at this time on days 20 and 21). Mean soil saturation values were taken, using a portable soil acidity and moisture meter, from 10 randomly selected plants at the $0930 \mathrm{~h}$ observation time for each day of trial 2. Environmental variables were similar for both trials: temperatures ranged from about 19 to $21^{\circ} \mathrm{C}$ at the beginning and $31-34^{\circ} \mathrm{C}$ at the end of anthesis each day. Relative humidity ranged from $84 \%$ to $90 \%$ at the beginning and $43-52 \%$ at the end of anthesis. 


\subsection{Field studies: bagged flowers}

To determine if the nectar patterns observed under greenhouse conditions were present under open field conditions, two trials were conducted during 2008 (trial $1=11-13$ August; trial 2=3-5 September) at the Kingsport campus of East Tennessee State University, Kingsport, Tennessee. For each trial, squash were grown from seed in newly plowed soil, augmented with composted manure, in four rows with approximately 50 plants per row. Nectar volume and concentration samples (as in "Greenhouse study: nectar secretion patterns") were taken from flowers in randomly selected plants for three consecutive days at 1.5 -h intervals, beginning at 0600 and ending at $1200 \mathrm{~h}$. Bridal veil, shown to affect nectar volume and concentration the least of any bagging technique currently used (Wyatt et al. 1992), was fitted to blossoms set to open the following day, thus preventing insect visits. In trial 1 , samples were taken from eight to 10 flowers at each sample time each day except for the $1200 \mathrm{~h}$ sample time on day 3, for which only one open flower was available. In trial 2, eight flowers were sampled at each sample time each day. The rates of nectar sugar production were estimated in the same manner as in "Greenhouse study: nectar secretion patterns". For trial 1, honey bee foraging visits also were monitored (20 min per hour, from 0600 through $2000 \mathrm{~h}$ ) from three widely dispersed observation posts (patches) within the squash garden during the same days as nectar sampling. Observers simply noted the number of honey bee visits to a 2-m section (encompassing about four plants and 60-80 flowers) of one row of squash plants. Each entry by a honey bee to the patch was counted as a single visit, even if several flowers within the patch were attended. Honey bees were not individually marked.

\subsection{Field studies: standing crop and insect visits}

Standing crop was determined in two separate trials. Each trial was conducted on a separate group of plants grown from seed in newly plowed soil (near Johnson City, Tennessee) augmented with composted manure. Nectar volume and concentration measures were taken hourly throughout anthesis using randomly selected flowers. In trial 1, 33 plants (in two rows) were sampled over 3 days (7-9 July, 2009). In trial 2, 60 plants (in four rows) were sampled over 2 days (10-11 August, 2009). Samples were taken from 10-13 flowers at each sample time. Within each trial, nectar measures were pooled to determine hourly standing crop values. For trials 1 and 2 , there were a total of $8-11$ and 10-13 flowers, respectively, for each hourly sample. Environmental conditions were similar between the two trials. At the beginning of anthesis, temperatures ranged from 16 to $22{ }^{\circ} \mathrm{C}$ and relative humidity from $63 \%$ to $78 \%$. At the end of anthesis, temperatures ranged from 26 to $30^{\circ} \mathrm{C}$ and relative humidity from $53 \%$ to $74 \%$. The squash gardens from each trial were also monitored for the timing of pollinator visits: one observer (DM) slowly walked through the rows in the same sequence (twice) for the first 20 min of each hour, noting the visits of all insects on squash flowers. For trial 1, insects were monitored from 0600 through $1700 \mathrm{~h}$ on 11, 12, 14, and 15 July, 2009. For trial 2, the survey was conducted from 0600 through $1300 \mathrm{~h}$ on 13-15 August, 2009. Sweat bees (Family Halictidae), bumble bees (Bombus spp.), squash bees (Peponapis and Xenoglossa spp.), and honey bees (Apis mellifera) were predominate.

In trial 2, pollen counts were made from the same flowers that were sampled for nectar measurements. These counts were made throughout anthesis in order to correlate pollen disappearance (i.e., removal by bees) with the ongoing daily changes in nectar properties and with the temporal distributions of the different bee visitors. Anthers were collected in the field with forceps and small scissors, and then stored individually in 1.5-ml PCR tubes. Later, each anther was submerged in $10 \mathrm{ml}$ of deionized water. One drop of Tween 80 was added to prevent clumping of pollen grains and Saffranin $\mathrm{O}$ was added to facilitate visualization for counting. The solution containing the anther and pollen grains was then shaken vigorously and $0.1 \mathrm{ml}$ was removed using a calibrated micropipette. The sample was placed on a hand-gridded slide and all pollen grains were counted. Three samples were taken from each tube: the average number of grains was multiplied by 100 to estimate the total number of pollen grains per anther.

\subsection{Analyses}

SPSS 16.0 (SPSS Inc., Chicago, USA) and StatMost 3.0 (DataMost Corp., Sandy, UT, USA) were used for statistical analyses. For the greenhouse and field studies 
with bagged flowers, nectar volumes and concentrations were analyzed by two-way ANOVA with time of day (i.e., sampling time) and date (i.e., day of experiment) as factors. In cases of non-normality, data were square-root transformed. For the field study involving standing crop, one-way ANOVA tests were used to determine the effect of time of day on nectar volume, nectar concentration, and number of pollen grains per anther. Post hoc comparisons were accomplished with Tukey's HSD and Duncan's multiple range tests.

\section{RESULTS}

\subsection{Greenhouse study: nectar secretion patterns}

Under greenhouse conditions, male squash flowers exhibited a consistent daily pattern of changes in nectar volume and concentration during anthesis. The temperature and humidity profiles were similar between the two trials, with temperatures near $20^{\circ} \mathrm{C}$ at the beginning and about $35^{\circ} \mathrm{C}$ at the end of anthesis. Relative humidity values were relatively high $(71-87 \%)$ at the beginning and relatively low $(26-45 \%)$ at the end of anthesis. Although the flowers opened before sunrise, they typically contained, at the beginning of anthesis, either no measurable nectar or very small volumes $(<1 \mu \mathrm{l})$ of highly concentrated (about $38-42 \% \mathrm{w} / \mathrm{w}$ ) nectar. Over the next several hours, however, nectar volume increased and nectar concentration decreased (Figure 1). Two trials were conducted, each over three consecutive days: the nectar volume and concentration patterns were remarkably similar from day to day. In trial 1 , for example, in the analysis of concentration, time of day $\left(F_{4,89}=33.38, P<\right.$ $0.001)$ was a significant factor but date $\left(F_{2,89}=\right.$ $0.76, P=0.47)$ and the interaction of time of day with date $\left(F_{8,89}=1.0, P=0.44\right)$ were not. With respect to nectar volume, time of day $\left(F_{5,105}=\right.$ $39.38, P<0.001)$ was a significant factor but date $\left(F_{2,105}=1.83, P=0.17\right)$ and the interaction of the two factors $\left(F_{10,105}=0.52, P=0.87\right)$ were not. Similar results were obtained in trial 2 (Figure 1). For concentration, time of day was a significant factor $\left(F_{5,85}=32.59, P<0.001\right)$ but date $\left(F_{2,85}=\right.$ $1.67, P=0.20)$ and the interaction of time of day with date $\left(F_{10,85}=1.50, P=0.16\right)$ were not. In the analysis of volume, time of day was significant $\left(F_{5,98}=34.45, P<0.001\right)$ but neither date $\left(F_{2,98}=\right.$ $0.19, P=0.83)$ nor the interaction $\left(F_{10,98}=0.29\right.$, $P=0.98)$ were. The greatest rates of nectar sugar production occurred approximately at mid-anthesis in both trials (Table I), as would be expected from a profile (Figure 1) showing the greatest increases in volume during mid-anthesis, concurrent with relatively high sugar concentrations.

\subsection{Greenhouse study: simulated drought}

Under greenhouse conditions, two trials were conducted to determine the potential effect of simulated drought on the daily nectar secretion patterns. In the first trial, date was a significant factor for both the volume $\left(F_{15,956}=4.88, P<\right.$ $0.001)$ and concentration of nectar $\left(F_{15,733}=\right.$ 21.14, $P<0.001)$; Tukey's HSD post hoc tests revealed that both characteristics showed a significant $(P<0.05)$, gradual decline in amplitude throughout the simulated drought. Despite these changes in amplitude, the basic nectar patterns observed in the first greenhouse study ("Greenhouse study: nectar secretion patterns") persisted. Maintenance of these diel patterns (a gradual increase in nectar volume in concert with a gradual decrease in concentration progressing from flower opening before sunrise to closing at midday) was reflected in the fact that time of day was a significant factor for both volume $\left(F_{5,956}=227.40, P<0.001\right)$ and concentration $\left(F_{5,733}=211.10, P<0.001\right)$. The interaction of time of day with date was not a significant factor for volume $\left(F_{73,956}=1.23, P=\right.$ $0.10)$ nor for concentration $\left(F_{66,733}=34.86, P=\right.$ $0.07)$. In the second trial, soil moisture levels were monitored daily throughout the duration of the experiment (Figure 2). Similar to the results from trial 1 , the basic nectar patterns seen in the first greenhouse study were maintained throughout the duration of the experiment. These are illustrated in Figure 2 for day 1 (pre-drought), day 13 (mid-drought), day 20 (late drought), and day 25 (fifth day post-drought). Thus, time 


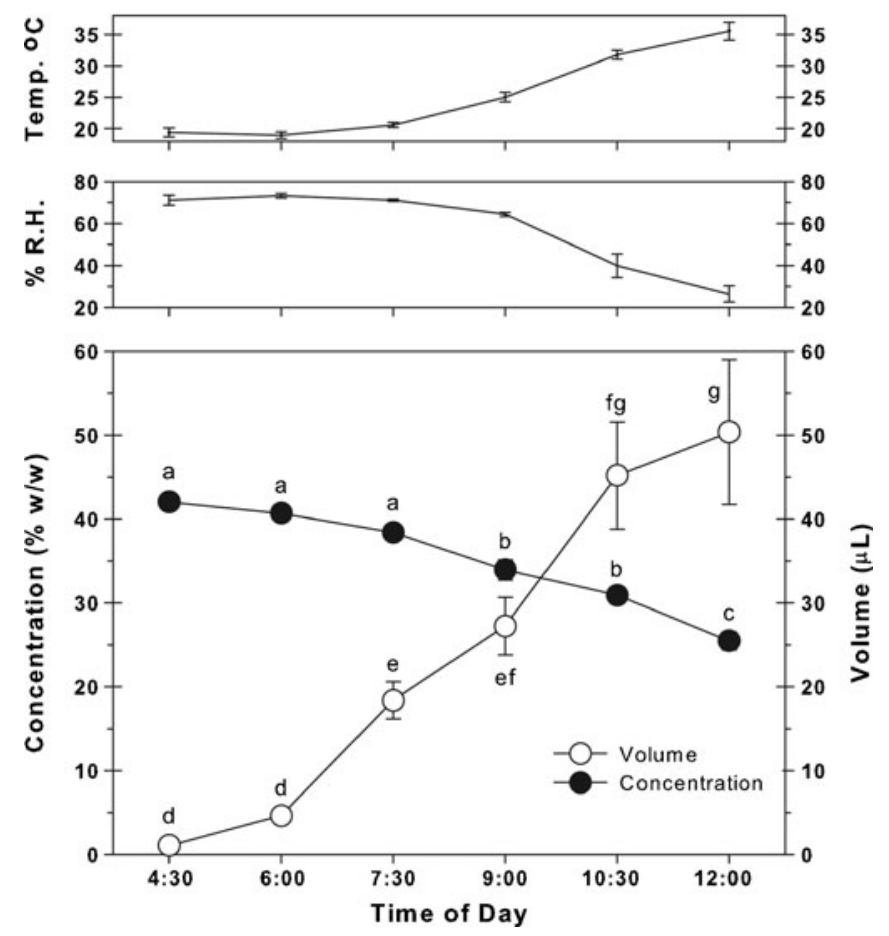

Figure 1. Diel nectar secretion patterns through anthesis in male squash flowers under greenhouse conditions. Data were collected at 1.5-h intervals. Volume and concentration measures (bottom panel) as well as temperature and relative humidity values (top and middle panels, respectively) are depicted as means $\pm \mathrm{SE}$. Different letters indicate significant differences (Tukey's HSD post hoc test, $P<0.05$ ).

of day was a significant factor for both volume $\left(F_{5,1397}=480.75, P<0.001\right)$ and concentration $\left(F_{5,116}=8698.50, P<0.001\right)$. The persistence of the daily nectar secretion patterns throughout the 16 consecutive days of simulated drought occurred, as in trial 1, despite progressive reductions in both nectar volume and concentration during the drought period (Figure 3). Accordingly, date was a significant factor for both volume $\left(F_{24,1397}=9.37, P<0.001\right)$ and concentration $\left(F_{24,1116}=181.26, P<0.001\right)$. The interaction of time of day with date was a

Table I. Estimated rates of nectar sugar production through anthesis, for both trials of the greenhouse study examining basic nectar secretion patterns.

Trial 1

Sample time

5:00-6:30

6:30-8:00

8:00-9:30

9:30-11:00

11:00-12:30
Trial 2

Sample time

Rate $(\mathrm{mg} / \mathrm{h})$

$\begin{array}{cc}4: 30-6: 00 & 1.1 \\ 6: 00-7: 30 & 4.3 \\ 7: 30-9: 00 & 2.5 \\ 9: 00-10: 30 & 4.4 \\ 10: 30-12: 00 & 1.1\end{array}$

2.0

4.5

4.1

3.8

\begin{tabular}{l}
1.4 \\
2.0 \\
4.5 \\
4.1 \\
3.8 \\
\hline
\end{tabular}

1.4
2.0
4.5
4.1
3.8

\begin{tabular}{l}
1.4 \\
2.0 \\
4.5 \\
4.1 \\
3.8 \\
\hline
\end{tabular}




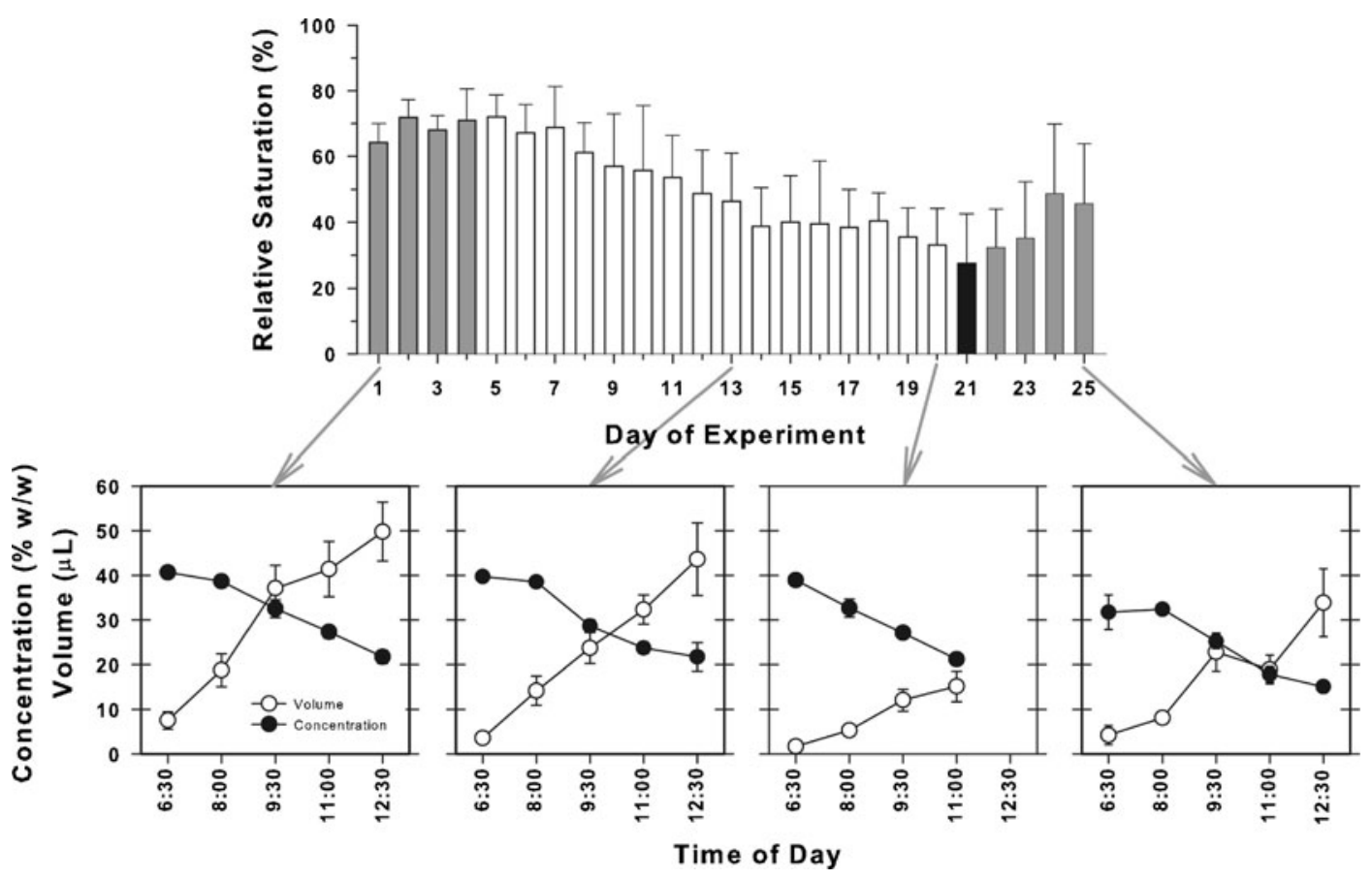

Figure 2. Diel nectar secretion patterns persist through simulated drought conditions in the greenhouse. Relative soil saturation values are depicted (mean \pm SE) for each day of the experiment. The amount of water provided per plant each day was $500 \mathrm{ml}$ (baseline conditions, days 1-4), no water (drought conditions, days 5-20), 1,000 $\mathrm{ml}$ (simulated rain event, day 21), and $500 \mathrm{ml}$ again (resumption of baseline conditions, days 22-25). Nectar volume and concentration measures (means \pm SE) through anthesis are shown for days 1, 13, 20, and 25 (bottom panels). No nectar measures were taken at the $1230 \mathrm{~h}$ sample time on day 20 because all flowers were closed.

significant factor for volume $\left(F_{117,1397}=1.54\right.$, $P<0.001)$ but not for concentration $\left(F_{99,1116}=\right.$ 17.93, $P=0.70)$. The decline in amplitude of nectar volume from pre-drought levels was significant by day 12 (Tukey's HSD post hoc tests, $P<0.05)$. The decline in amplitude for concentration was more gradual: levels were not significantly different (Tukey's HSD post hoc test, $P<0.05)$ from pre-drought values until day 21 (first day post-drought). For both nectar volume and concentration, the amplitudes continued to decrease into the post-drought period.

\subsection{Field studies: bagged flowers and honey bee visits}

Two trials confirmed that the daily nectar secretion patterns (volume and concentration) observed in the greenhouse studies ("Greenhouse study: nectar secretion patterns" and "Green house study: simulated drought") are also found under field conditions. In trial 1, regarding concentration (Figure 4), time of day was a significant factor $\left(F_{4,84}=6.00, P<0.001\right)$ but date $\left(F_{2,84}=2.28, P=0.11\right)$ and the interaction of time of day and date $\left(F_{7,84}=1.37, P=0.232\right)$ were not. Concerning volume (Figure 4$)$, time of day $\left(F_{4,114}=67.34, P<0.001\right)$ and date $\left(F_{2,114}=7.74\right.$, $P=0.001)$ were significant factors, but the interaction was not $\left(F_{8,114}=1.12, P=0.36\right)$. The same trends were observed in trial 2 . As in trial 1 , with respect to concentration, time of day was a significant factor $\left(F_{4,87}=20.07, P<0.001\right)$ but date $\left(F_{2,87}=0.85, P=0.43\right)$ and the interaction $\left(F_{8,87}=0.62, P=0.76\right)$ were not. Also, as in trial 1 , considering volume, time of day $\left(F_{4,119}=24.32\right.$, 


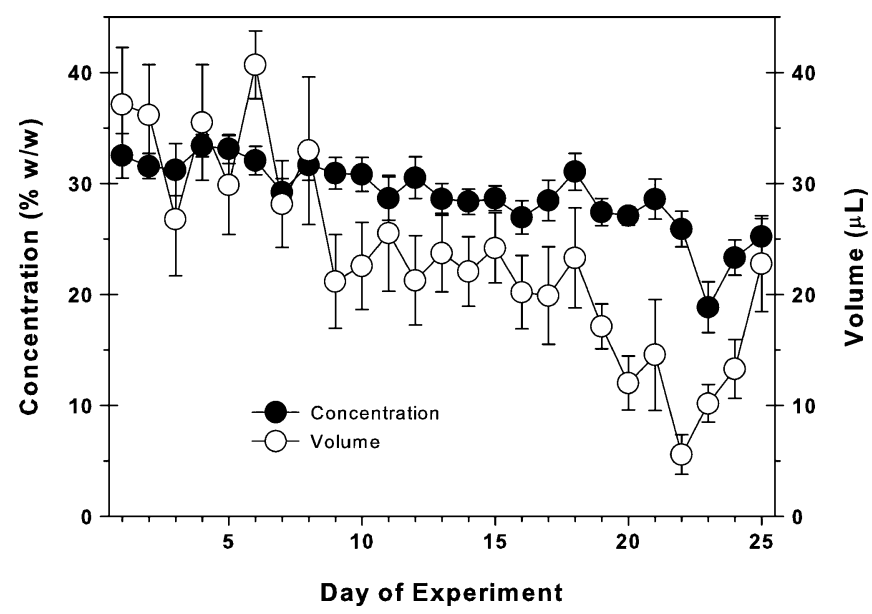

Figure 3. Nectar volumes and concentrations per flower show gradual declines in amplitude through simulated drought experiment (see Figure 2). Data (means \pm SE) are shown for the $0930 \mathrm{~h}$ sample time.

$P<0.001)$ and date $\left(F_{2,119}=4.79, P=0.01\right)$ showed significance as factors, but the interaction did not $\left(F_{8,119}=1.98, P=0.06\right)$. Thus, for both field trials, volume showed significant dayto-day variability, but concentration did not. In trial 1, honey bee visits to the squash garden (Figure 4) did not begin before sunrise (approximately $0645 \mathrm{~h}$ ) with the beginning of anthesis. Instead, they began about $0700 \mathrm{~h}$, maintained high levels of visitation from 0800 to $1000 \mathrm{~h}$, reduced their visits during the late portions of anthesis, and showed virtually no visits after the flowers had closed. As in the greenhouse studies, the greatest rates of nectar sugar production occurred at mid-anthesis (Table II). The sample time with the greatest nectar sugar production rate $(0730-0900 \mathrm{~h})$ coincided with the highest levels of honey bee visitation (0800-0900 h).

\subsection{Field studies: standing crop}

Standing crop measurements (Figure 5) showed that nectar volumes, in sharp contrast to the patterns observed in the greenhouse studies and field studies with bagged flowers, remained at very low levels throughout anthesis and peaked at about $0900 \mathrm{~h}$ in trial 1 and about $0800 \mathrm{~h}$ in trial 2 . Time of day was a marginally significant factor for volume in trial $1\left(F_{7,76}=\right.$
2.21, $P=0.04)$ : the only significant pair-wise differences among sample times involved the peak volume at $0900 \mathrm{~h}$ with those at 0600, 0700, 0800, and $1200 \mathrm{~h}$ (Duncan's multiple range test, $P<0.05)$. Time of day was not a significant factor for volume in trial $2\left(F_{6,78}=1.45, P=0.21\right)$. In contrast with the volume measurements, nectar concentrations in the standing crop were similar to those observed in the greenhouse and bagged flower studies with respect to both the amplitudes and daily patterns of change during anthesis (compare Figure 5 with Figures 1, 2, and 4). Accordingly, time of day was a significant factor influencing concentration for both trials (trial $1-F_{6,52}=12.39, P<0.001$; trial $2-$ $\left.F_{5,23}=14.18, P<0.001\right)$. In trial 2, pollen counts were made on the same flowers sampled for nectar measurements (Figure 5). Time of day was a significant factor for number of pollen grains $\left(F_{6,84}=79.46, P<0.001\right)$, with the number of pollen grains/anther diminishing quickly after the onset of anthesis (Tukey's HSD post hoc test, $P<0.05$ ). For example, only about $6.5 \%$ of the original number of pollen grains/anther remained by $0800 \mathrm{~h}$. By $0900 \mathrm{~h}$, this number was only about $3 \%$.

The timing of pollinator visits was monitored for both trials, yielding similar results (Figure 6). Because of the sampling regime (survey during 

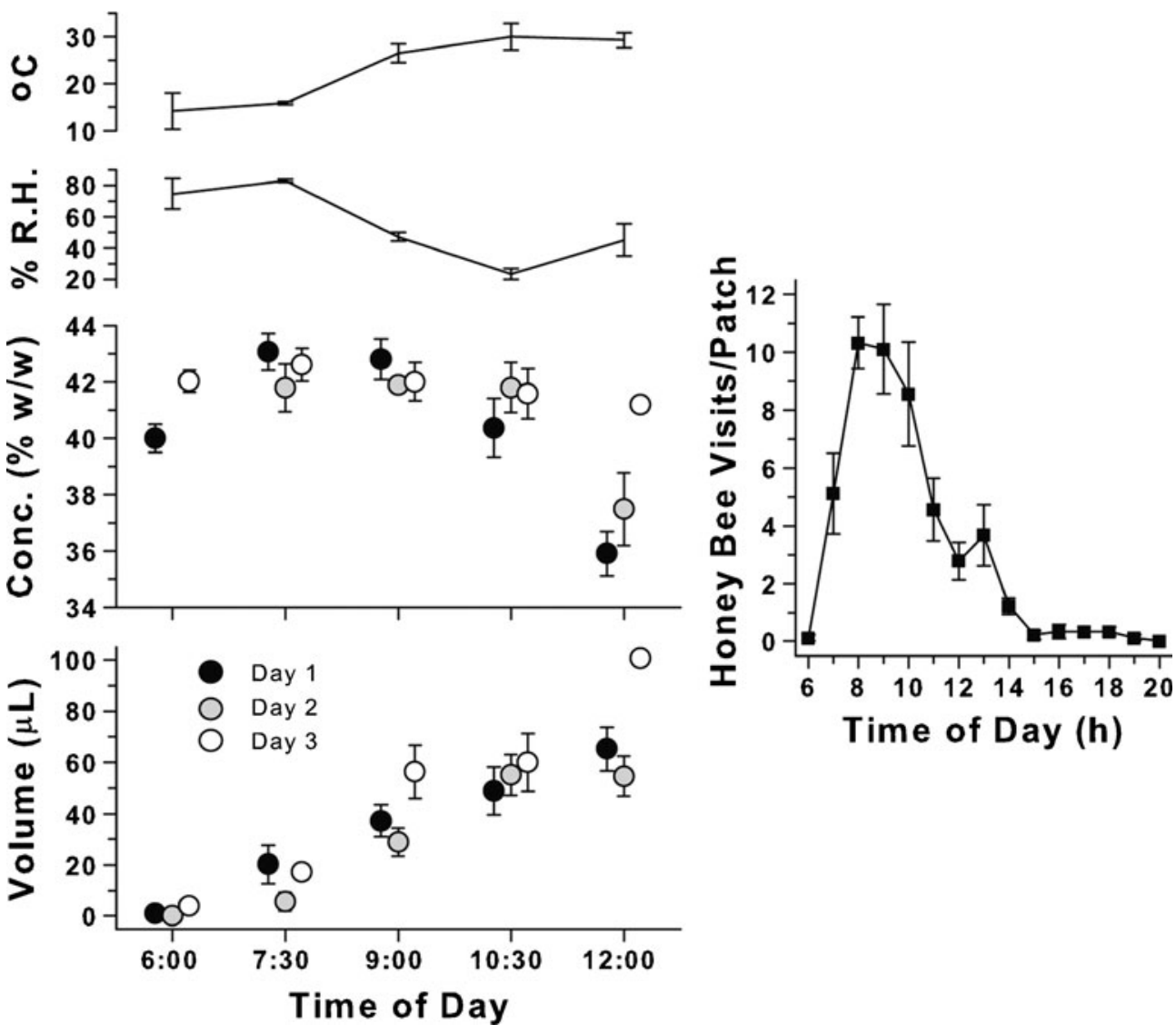

Figure 4. Diel nectar secretion patterns persist under field conditions. Left panels, from top to bottom, indicate temperature, relative humidity, nectar concentration, and nectar volume measures taken at 1.5 -h increments through anthesis. Temperature and relative humidity values were averaged over the 3 days of the experiment. Concentration and volume measures (from bagged flowers) are shown for each day (black, gray, and white circles for days 1, 2, and 3, respectively). Right panel: mean number ( $\pm \mathrm{SE})$ of honey bee visits per observation patch for three separate patches over the same three consecutive days as nectar sampling.

Table II. Estimated rates of nectar sugar production through anthesis, for both trials of the field study with bagged flowers.

Trial 1

Sample time

6:00-7:30

7:30-9:00

9:00-10:30

10:30-12:00
Trial 2

Sample time

Rate $(\mathrm{mg} / \mathrm{h})$

$\begin{array}{cc}6: 00-7: 30 & 0.7 \\ 7: 30-9: 00 & 4.6 \\ 9: 00-10: 30 & 5.6 \\ 10: 30-12: 00 & 0.5\end{array}$


Trial 1
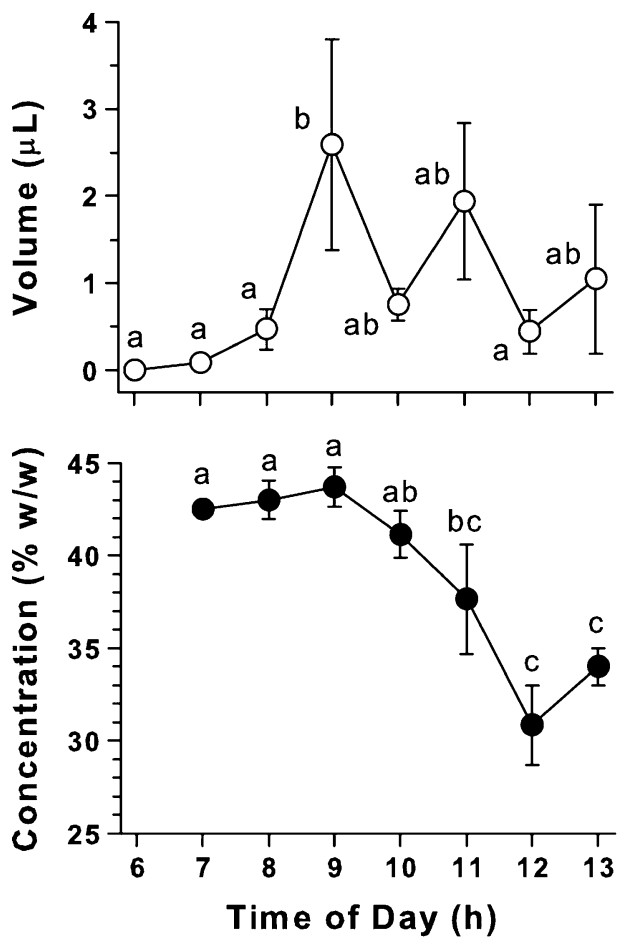

Trial 2
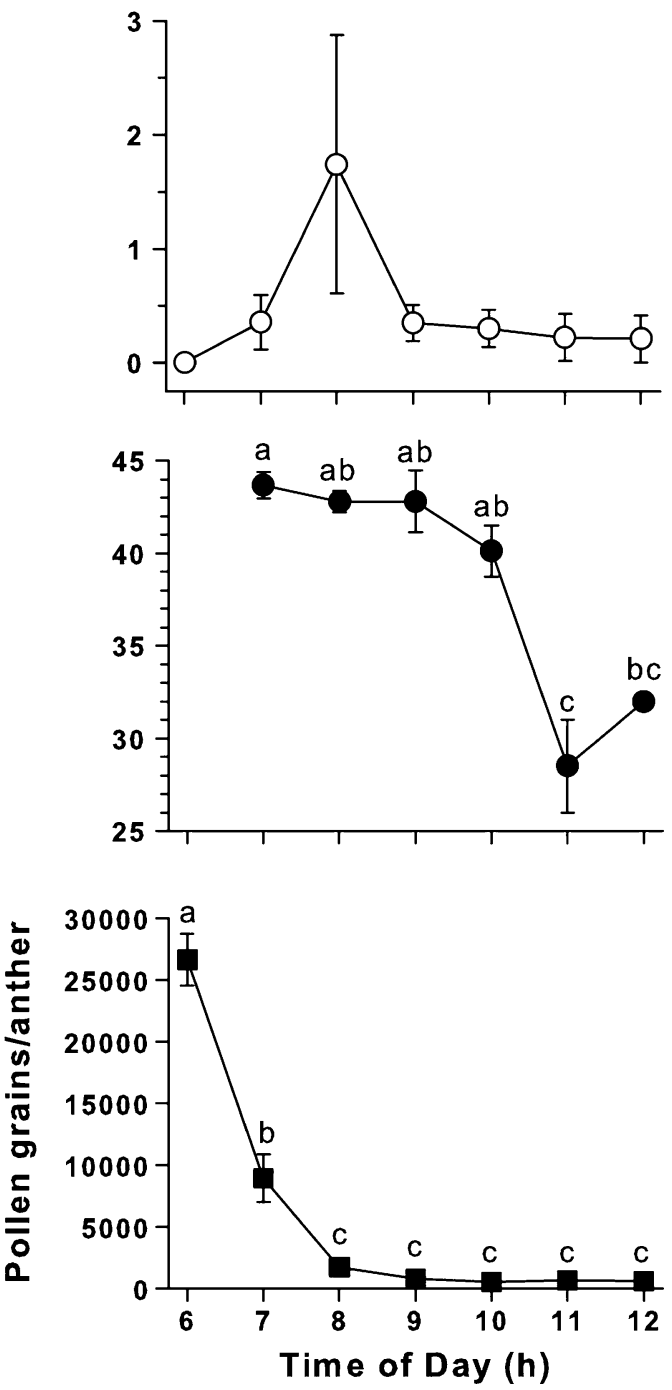

Figure 5. Standing crop measures (nectar volume and concentration) at hourly intervals through anthesis for trial 1 (left panels) and trial 2 (right panels). Pollen grains per anther were measured for the same flowers used for the nectar samples in trial 2 (bottom right panel). Data are means \pm SE. Different letters indicate significant differences $(P<0.05)$.

slow walk along rows of squash plants; see "Materials and methods"), the presence of a bee within the observed area was considered a visit. Thus, we were not monitoring visits to individual flowers but rather visits to the squash patch. Squash bees and bumble bees were the earliest to visit the squash plants; both began arriving shortly before (trial 1) or shortly after (trial 2) sunrise. Although both the squash bees and bumble bees continued to visit the flowers until they closed between 1200 and $1300 \mathrm{~h}$, the frequency of their visits tapered off after about 1000 h. Halictids began visiting the flowers approximately $1 \mathrm{~h}$ (trial 1 ) or $2 \mathrm{~h}$ (trial 2) later 
than did the squash bees and bumble bees; they maintained a high frequency of visitation until the flowers closed. Honey bees were the last (and least numerous) pollinators to show up, appearing mostly during the 0900 and $1000 \mathrm{~h}$ observation times in trial 1 and the 1000 and $1100 \mathrm{~h}$ observation times in trial 2 . The reason for the delay in visits observed in trial 2 (midAugust) relative to trial 1 (mid-July) is not known but perhaps may be attributed, at least partially, to the shortened daylength.

\section{DISCUSSION}

Relatively few flowers in nature provide ad libitum access to nectar. Most species limit visitor access to restricted time-windows of availability (Linnaeus 1751; von Buttel-Reepen 1900; Parker 1925; Kleber 1935). However, what may be happening to the nectar within these time-windows (i.e., temporal changes in quantity and/or quality) has not been described for the vast majority of species.

\section{Trial 1}
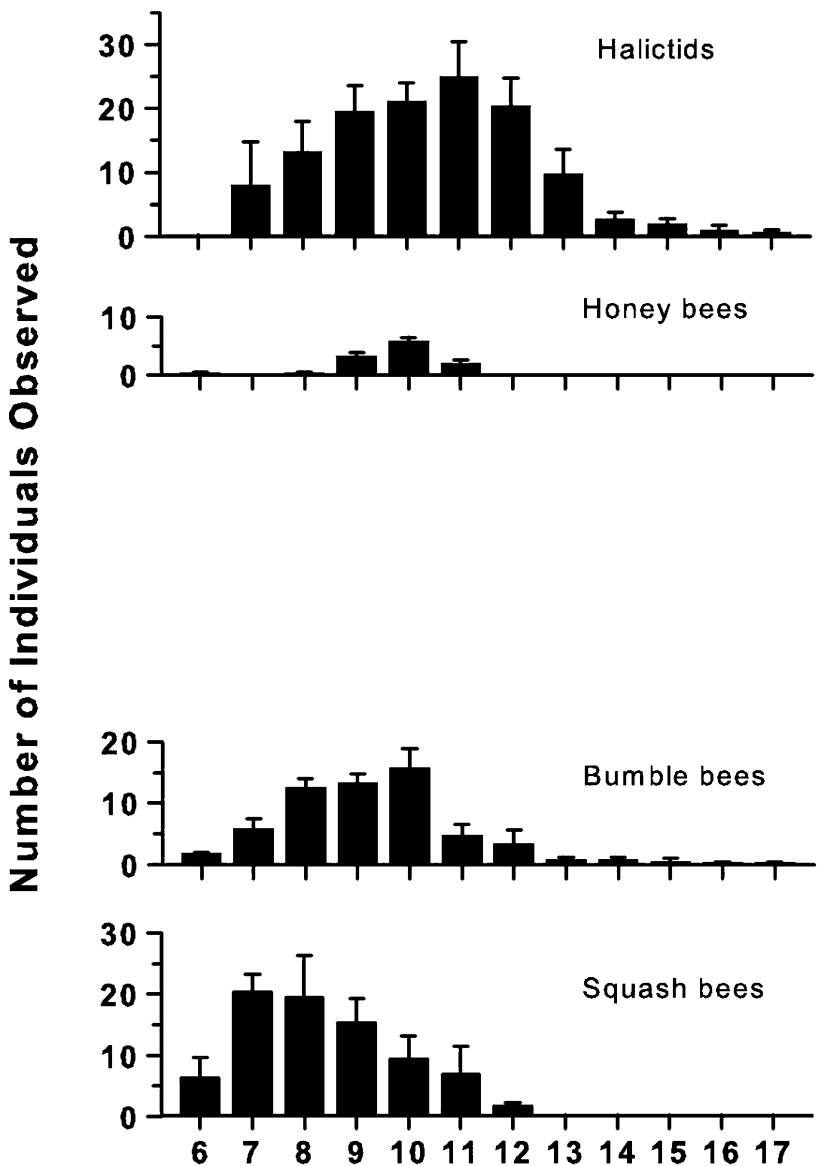

Trial 2
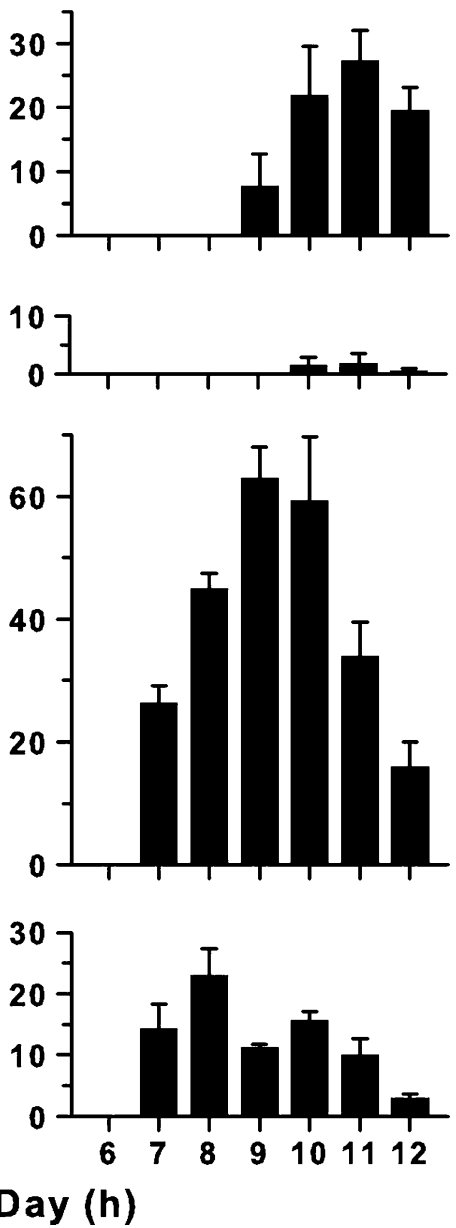

Figure 6. Insect visits to squash flowers monitored hourly over 4 days (trial 1, left panels) and 3 days (trial 2, right panels), using the same plantings as the standing crop measures (Figure 5). Note delay in honey bee visits relative to those of squash bees and bumble bees. Data are depicted as means $\pm \mathrm{SE}$. 
Our results show a consistent daily pattern of nectar secretion in male squash flowers $(C$. pepo, variety 'Summer Crookneck'). As reported for other cucurbits, the flowers open just before sunrise and close at midday (Canto-Aguilar and Parra-Tabla 2000; Nepi et al. 2001). Nectar volumes are very small at the beginning of anthesis, but increase through the morning hours, with the greatest changes in volume occurring at mid-morning. Nectar concentrations are highest at the onset of nectar secretion and exhibit a gradual dilution through the morning. These diel patterns (Figure 1) show little day-to-day variability under greenhouse conditions: date was not a significant factor determining either volume or concentration in two separate trials. The relative changes of nectar volumes and concentrations through anthesis yield the greatest nectar sugar production rates at mid-anthesis, with relatively low sugar production rates at the beginning and end (Table I).

The diel nectar patterns were found to be quite robust. Both the volume and concentration patterns continued, in two separate trials, under simulated drought conditions in the greenhouse (Figure 2). Although the amplitudes of both nectar volume and concentration showed a gradual decrease under extended periods without water (Figure 3), the fundamental diel patterns persisted much as during non-drought conditions (compare Figures 1 and 2). Furthermore, the basic patterns observed in the greenhouse (increasing nectar volume and decreasing concentration through anthesis) were also present under field conditions (Figure 4). Although nectar volumes showed day-to-day variability in the field, nectar concentrations did not. Thus, we conclude that the basic diel patterns for volume and concentration during anthesis are an inherent property of the Summer Crookneck variety of $C$. pepo.

Our findings differ to some degree with those observed in two different varieties of C. pepo L. Rather than exhibiting a gradual but significant decrease through anthesis, nectar concentration remained constant in 'Greyzini' (Nepi et al. 2001) and constant until just before flower closing in the pumpkin 'Howden' (Vidal et al.
2006). Also, male flowers in 'Greyzini' produced most of their nectar before mid-anthesis, with no significant differences in volume between 0900 and $1200 \mathrm{~h}$ (Nepi et al. 2001). Similarly, in a different species of squash, Cucurbita moschata, nectar production peaked between 0700 and $0800 \mathrm{~h}$, although it continued (in decreasing amounts) until the flowers closed (Canto-Aguilar and Parra-Tabla 2000). In contrast, our squash plants showed significant production of nectar in the second half of anthesis, under both greenhouse and field conditions (Figures 1, 2, and 4; Tables I and II).

The data described in this study may influence the structuring of future experiments designed to mimic natural foraging conditions and how these conditions change throughout the day. Most previous studies on foraging behavior have relied on artificial food sources that do not accurately reflect the natural situation. Such studies may, as a result, yield unrealistic conclusions. One area of study that presumably could benefit from experiments employing more natural nectar rewards is the acquisition and maintenance of the honey bee time-memory. The time-memory enables the individual forager to make food-anticipatory flights to a specific food source at the appropriate time of day (Beling 1929; Wahl 1932; Renner 1955; Beier 1968; Beier and Lindauer 1970; Moore and Rankin 1983; Frisch and Aschoff 1987; Moore et al. 1989; Moore and Doherty 2009; Naeger et al. 2011). It is thought that timememories serve to minimize the number of nonproductive foraging flights directed to each particular food source by allowing honey bees to match their foraging excursions accurately with species-specific, daily rhythms of floral nectar and pollen availability. Our current understanding of the phenomenon is based largely on experiments using artificial food sources, typically involving ad libitum access at constant concentrations (e.g., Moore and Doherty 2009). The present work provides a foundation for investigating the linkage between diel nectar secretion patterns under natural conditions and establishment of the honey bee time-memory. The next step will involve extensive monitoring of individually marked bees at nectar sources 
with volumes and concentrations that vary authentically throughout artificial antheses.

The day-to-day constancy of the basic diel pattern of nectar secretion in Summer Crookneck squash appears to be consistent with a temporally predictable resource. How do honey bees, possessing the ability to learn the time and location of a food source (e.g., the time-memory), exploit this resource? If honey bee foragers primarily schedule their visits when the nectar concentration is highest (Wahl 1933; Kleber 1935; Butler 1945; Waller 1972; Seeley et al. 1991; Wolf et al. 1999), then (based on the diel patterns observed in this study) most of their visits should occur early in anthesis. On the other hand, if volume is the primary factor determining foraging behavior (Silva and Dean 2000), then most foraging visits should coincide with the availability of highest nectar volumes. This determination may be difficult against a background of nectar removals by many competing pollinators. Presumably, if a flower's nectar has recently been drained by another pollinator, then the time of day with the highest probability of generating sufficient nectar for the next visitor will correspond with the timing of that flower's highest secretion rates. The greenhouse and field studies with bagged flowers demonstrated that, in the absence of insect visits, nectar volume in Summer Crookneck squash accumulates throughout anthesis but the greatest secretion rates occur during mid-anthesis (Figures 1, 2, and 4). Alternatively, if honey bee foragers base their behavior on sugar flow rates (Varju and Nuñez 1991; Greggers et al. 1993; Wainselboim et al. 2002) or sugar quantity (Giurfa and Núñez 1992; Rabinowitch et al. 1993), then they should schedule their visits to Summer Crookneck squash during mid-anthesis, when the rates of nectar sugar production (a product of both volume and concentration) are highest (Tables I and II). In the present study, honey bees foraged on squash flowers during mid-anthesis in two trials (Figure 4 and trial 1 of Figure 6) and 1-2 h later in another (trial 2 of Figure 6). In all cases, there was intense competition from other pollinators. Honey bees did not schedule their foraging flights early in anthesis. Therefore, their foraging behavior was not matched with the first availability of highly concentrated nectar. This finding is unexpected, in light of the tendencies of honey bee foragers to (1) reconnoiter a profitable food source in anticipation of its time-window of availability (Moore and Doherty 2009) and (2) return to a food source at the time of day at which sucrose concentrations were highest on previous days (Wahl 1933). In contrast, both squash bees and bumble bees began visiting the squash flowers in large numbers early in anthesis and their visitation rates declined after midmorning (Figure 6). The apparent scheduling of honey bee visits later in anthesis relative to other bee pollinators has been observed previously in C. moschata in the Yucatan (Canto-Aguilar and Parra-Tabla 2000) and C. pepo, variety Northrup King Italian Black Zucchini, in Utah (Tepedino 1981). It must be emphasized here that the apparent time-niches for the different pollinators seen in the present study should be viewed as approximations: the bees were individually unidentifiable (i.e., unmarked), so the contribution of the individual to the group response is not possible to ascertain. Furthermore, the temporal behavior of individual foragers may be shaped not only by nectar secretion rhythms but also by the unique suite of competitive interactions among pollinators that occur at each locale.

To explore the relationship between the basic diel nectar secretion patterns and the availability of nectar when insect visits are unrestricted, standing crop was measured in two different trials. In both cases, nectar levels were very low through most of anthesis (Figure 5), reflecting a high degree of visitation from pollinators (Figure 6). The peak times of day for standing crop volumes occurred at (trial 1) or just before (trial 2) mid-anthesis for both trials, in close agreement with the times of day at which the highest nectar secretion rates were observed in the greenhouse and bagged flower studies. Although the numbers of visits by honey bees were relatively small in both trials, they occurred mostly at midanthesis in trial 1 , but $1-2 \mathrm{~h}$ later in trial 2 . The relative delay in honey bee visits during trial 2 (as well as the lower levels of standing crop volumes) possibly may be attributed to the higher levels of 
competition from bumble bees during midanthesis, compared to trial 1 (Figure 6). Interestingly, in both trials, honey bees visited the squash flowers long after most of the pollen was removed by the other bees (Figure 5). This finding supports the assertion that, in the presence of native pollinators, the use of honey bees for pollination of squash may be superfluous (Tepedino 1981; Canto-Aguilar and Parra-Tabla 2000).

Based on our measures of standing crop, it would seem that competition from many insect visitors yields a situation in which the likelihood of encountering flowers containing little or no nectar rewards is high. This scenario may favor a risk-aversive assessment of flower patch profitability in honey bee foragers, as demonstrated in artificial flower arrays (Seefeldt and De Marco 2008).

The present study provides a foundation for future studies examining pollinator behavior under natural conditions. We have found that the diel nectar secretion patterns through anthesis in squash flowers are quite predictable under a variety of conditions. Therefore, at least for this species, incorporating the daily changes in nectar volume and concentration within individual flowers may lead to more realistic experiments and models to investigate the strategies by which different pollinators efficiently gain energy while plants are maximizing pollination.

\section{ACKNOWLEDGMENTS}

We thank Huijing Sun, Caleb Paquette, Curt Gill, Joanna Magner, and Aprele Fitzgerald for valuable assistance with the greenhouse and 2008 field experiments. We very much appreciate the generosity of the ETSU Kingsport Campus for providing garden space and support for the 2008 field studies and Thomas Jones and Allison Mains for garden space and support at their farm in 2009. Financial support was provided by a grant from the United States Department of Agriculture, National Research Initiative, CSREES \#2006-3530217278 (DM).

Rythme journalier de la secrétion de nectar chez la courge (Cucurbita pepo) et relation avec l'activité des pollinisateurs

\begin{abstract}
Abeilles / butinage / nectar / pollinisateur / comportement
\end{abstract}

Tagesrhythmik der Nektarsekretion im Kürbis (Cucurbita pepo) und seine Beziehung zur Bestäuberaktivität

\section{Bienen / Sammelverhalten / Nektar / Bestäuber / Verhalten}

\section{REFERENCES}

Beier, W. (1968) Beeinflussung der inneren Uhr der Bienen durch Phasenverschiebung des LichtDunkel-Zeitgebers. Z Bienenforschung 9, 356-378

Beier, W., Lindauer, M. (1970) Der Sonnenstand als Zeitgeber für die Biene. Apidologie 1, 5-28

Beling, I. (1929) Über das Zeitgedächtnis der Bienen. Z. Vergl. Physiol. 9, 259-338

Boch, R. (1956) Die Tänze der Bienen bei nahen und fernen Trachtquellen. Z. Vergl. Physiol. 38, 136-167

Bolten, A.B., Feinsinger, P., Baker, H.G., Baker, I. (1979) On the calculation of sugar concentration in flower nectar. Oecologia 41, 301-304

Butler, C.G. (1945) The influence of various physical and biological factors of the environment on honeybee activity: an examination of the relationship between activity and nectar concentration and abundance. J. Exp. Biol. 21, 5-12

Canto-Aguilar, M.A., Parra-Tabla, V. (2000) Importance of conserving alternative pollinators: assessing the pollination efficiency of the squash bee, Peponapis limitaris in Cucurbita moschata. J. Insect Conserv. 4, 203-210

Corbet, S.A. (1978) Bee visits and the nectar of Echium vulgare L. and Sinapis alba L. Ecol. Entomol. 3, 25-37

Corbet, S.A., Delfosse, E.S. (1984) Honeybees and the nectar of Echium plantagiueum L. in southeastern Australia. Aust. J. Ecol. 9, 125-139

Corbet, S.A., Wilmer, P.G. (1981) The nectar of Justicia and Columnea: composition and concentration in a humid, tropical climate. Oecologia 51, 412-418

Corbet, S.A., Willmer, P.G., Beament, J.W.L., Unwin, D.M., Prys-Jones, O.E. (1979) Post-secretory determinants of sugar concentration in nectar. Plant Cell Environ. 2, 293-308

Frisch, B., Aschoff, J. (1987) Circadian rhythms in honeybees: entrainment by feeding cycles. Physiol. Entomol. 12, 41-49 
Giurfa, M., Núñez, J.A. (1992) Foraging by honeybees on Carduus acanthoides: pattern and efficiency. Ecol. Entomol. 17, 326-330

Greggers, U., Kuettner, A., Mauelshagen, J., Menzel, R. (1993) Optimization of honeybees with balanced US-qualities. In: Elsner, N., Heisenberg, M. (eds.) Gene-Brain-Behavior, Proceedings of the $21^{\text {st }}$ Göttingen Neurobiology Conference, p. 841. Georg Thieme, Stuttgart

Kearns, C.A., Inouye, D.W. (1993) Techniques for pollination biologists. University Press of Colorado, Niwot

Kleber, E. (1935) Hat das Zeitgedächtnis der Bienen biologische Bedeutung? Z. Vergl. Physiol. 22, 221-262

Lindauer, M. (1948) Über die Einwirkung von Duft- und Geschmacksstoffen sowie underer Faktoren auf die Tänze der Bienen. Z. Vergl. Physiol. 31, 348-412

Linnaeus, C. (1751) Philosophia botanica. Kiesewetter, Stockholm

Louw, G.N., Nicolson, S.W. (1983) Thermal, energetic, and nutritional considerations in foraging and reproduction of the carpenter bee Xylocopa capitata. J. Ent. Soc. S. Africa 46, 227-240

Moore, D., Doherty, P. (2009) Acquisition of a timememory in forager honey bees. J. Comp. Physiol. A 195, 741-751

Moore, D., Rankin, M.A. (1983) Diurnal changes in the accuracy of the honeybee foraging rhythm. Biol. Bull. 164, 471-482

Moore, D., Siegfried, D., Wilson, R., Rankin, M.A. (1989) The influence of time of day on the foraging behavior of the honeybee, Apis mellifera. J. Biol. Rhythms 4, 305-325

Naeger, N., Van Nest, B.N., Johnson, J.N., Boyd, S.D., Southey, B.R., Rodriguez-Zas, S.L., Moore, D., Robinson, G.E. (2011) Neurogenomic signatures of spatiotemporal memories in time-trained forager honey bees. J. Exp. Biol. 214, 979-987

Nepi, M., Guarnieri, M., Pacini, E. (2001) Nectar secretion, reabsorption, and sugar composition in male and female flowers of Cucurbita pepo. Int. J. Plant Sci. 162, 353-365

Nieh, J.C., Contrera, F.A.L., Ramirez, S., ImperatrizFonseca, V.L. (2003) Variation in the ability to communicate three-dimensional resource location by stingless bees from different habitats. Anim. Behav. 66, 1129-1139

Nuñez, J.A. (1966) Quantitative Beziehungen zwischen den Eigenschaften von Futterquellen und den Verhalten von Sammelbienen. Z. Vergl. Physiol. 53, 142-164

Nuñez, J.A. (1977) Nectar flow by melliferous flora and gathering flow by Apis mellifera ligustica. J. Insect Physiol. 23, 265-275

Parker, R.L. (1925) The collection and utilization of pollen by the honeybee. Cornell University Press, Ithaca

Proctor, M., Yeo, P., Lack, A. (1996) The natural history of pollination. HarperCollins, London
Rabinowitch, H.D., Fahn, A., Meir, T., Lensky, Y. (1993) Flower and nectar attributes of pepper (Capsicum annuum L.) plants in relation to their attractiveness to honeybees (Apis mellifera L.). Ann. Appl. Biol. 123, 221-232

Renner, M. (1955) Über die Haltung von Bienen in geschlossenen, künstlich beleuchteten Räumen. Naturwissenschaften 42, 539-540

Schua, L. (1952) Untersuchungen über den Einfluss meteorlogischer Elemente auf das Verhalten der Honigbiene (Apis mellifica). Z. Vergl. Physiol. 34, 258-277

Seefeldt, S., De Marco, R.J. (2008) The response of the honeybee dance to uncertain rewards. J. Exp. Biol. 211, 3392-3400

Seeley, T.D. (1986) Social foraging by honeybees: how colonies allocate foragers among patches of flowers. Behav. Ecol. Sociobiol. 19, 343-354

Seeley, T.D. (1989) Social foraging in honeybees: how nectar foragers assess their colony's nutritional status. Behav. Ecol. Sociobiol. 24, 181-199

Seeley, T.D. (1995) The wisdom of the hive. Harvard University Press, Cambridge

Seeley, T.D., Camazine, S., Sneyd, J. (1991) Collective decision-making in honey bees: how colonies choose among nectar sources. Behav. Ecol. Sociobiol. 28, 277-290

Silva, E.M., Dean, B.B. (2000) Effect of nectar composition and nectar concentration on honey bee (Hymenoptera: Apidae) visitations to hybrid onion flowers. J. Econ. Entomol. 93, 1215-1221

Tepedino, V.J. (1981) The pollination efficiency of the squash bee (Peponapis pruinosa) and the honey bee on summer squash (Cucurbita pepo). J. Kansas Entomol. Soc. 54, 359-377

Vansell, G.H. (1934) Relation between the nectar concentration in fruit blossoms and the visits of honeybees. J. Econ. Entomol. 2, 943-945

Varju, D., Nuñez, J.A. (1991) What do foraging honeybees optimize? J. Comp. Physiol. A 169, 729-736

Vidal, M.D., De Jong, D., Wien, H.C., Morse, R.A. (2006) Nectar and pollen production in pumpkin (Cucurbita pepo L.). Revista Brasil. Bot. 2, 267273

Visscher, P.K., Seeley, T.D. (1982) Foraging strategy of honeybee colonies in a temperate deciduous forest. Ecology 63, 1790-1801

von Buttel-Reepen, H.B. (1900) Sind die Bienen Reflexmaschinen? Biol. Zbl. 20, 1-82

von Frisch, K. (1942) Die Werbetänze der Bienen und ihre Auslösung. Naturwissenschaften 30, 269-277

von Frisch, K. (1967) The dance language and orientation of bees. Harvard University Press, Cambridge

Waddington, K.D. (1982) Honeybee foraging profitability and round dance correlates. J. Comp. Physiol. 148, 279-301 
Waddington, K.D. (1985) Cost-intake information used in foraging. J. Insect Physiol. 31, 891-897

Wahl, O. (1932) Neue Untersuchungen über das Zeitgedächtnis der Bienen. Z. Vergl. Physiol. 16, 529-589

Wahl, O. (1933) Beitrag zur Frage des biologischen Bedeutung des Zeitgedächtnisses der Bienen. Z. Vergl. Physiol. 18, 709-717

Wainselboim, A.J., Roces, F., Farina, W.M. (2002) Honeybees assess changes in nectar flow within a single foraging bout. Anim. Behav. 63, 1-6
Waller, G.D. (1972) Evaluating responses of honey bees to sugar solutions using an artificial-flower feeder. Ann. Ent. Soc. Am. 65, 857-862

Wolf, S., Lensky, Y., Paldi, N. (1999) Genetic variability in flower attractiveness to honeybees (Apis mellifera L.) with the genus Citrullus. HortScience 34, 860863

Wyatt, R., Broyles, S.B., Derda, G.S. (1992) Environmental influences on nectar production in milkweeds (Asclepias syriaca and A. exaltata). Am. J. Bot. 79, 636-642 